JELENA SIMIĆEVIĆ

E-mail: j.simicevic@sf.bg.ac.rs

NADA MILOSAVLJEVIĆ, Ph.D.

E-mail: n.milosavljevic@sf.bg.ac.rs

University of Belgrade,

Faculty of Transport and Traffic Engineering

Vojvode Stepe 305, 11000 Belgrade, Serbia

GORAN MALETIĆ

E-mail: goran.maletic@institutims.rs

IMS Institute

Bulevar vojvode Mišića 43, Belgrade, Serbia
Transportation Economy

Review

Accepted: June 21, 2011

Approved: Oct. 3, 2012

\title{
INFLUENCE OF PARKING PRICE ON PARKING GARAGE USERS' BEHAVIOUR
}

\begin{abstract}
Parking charge is a powerful tool for solving parking and traffic congestion problems. In order to achieve the expected effects without any adverse impact it is necessary to understand well the users' responses to this policy. This paper, based on a sample of interviewed parking garage users, has developed binary logit model for identification and quantification of characteristics of users and trips, on which the acceptance of parking price is dependent. In addition, multinomial logit model has been made in order to predict what the users will opt for when faced with an increase in parking price. For the first time the parameter "shorten duration" has been introduced which has shown to be the most significant in making behaviour-related decisions. The results show that the users with the purpose work are the most sensitive to an increase in parking charge, what can be deemed positive for policy makers. However, great sensitivity of the users with the purpose shopping should cause their concern. The results of the multinomial model show that they would not discontinue coming into the area after all.
\end{abstract}

\section{KEY WORDS}

parking policy, parking charge, user behaviour, logit model, parking garages

\section{INTRODUCTION}

The mobility and motorization level record continuous increase in almost all countries in the world, which has led to the state in which traffic demand exceeds road capacity. As a consequence of this imbalance we are facing ever increasing network congestion. However, such imbalance between demand and capacity relates not only to movement infrastructure, but also to stationary vehicles - parking. In this sense vehicles travel additional distance in search of unoccupied parking space and some of them eventually park illegally on the street. This additionally contributes to creation of congestion and urban chaos.

In the past this problem used to be solved by expanding the capacity. Today, because of the costs and development issues in the conditions of limited resources, but also due to environmental concerns, such solution is not feasible any more or it is possible only to a small extent. The solution, therefore, does not lie in expansion, but rather in more efficient utilisation of the existing traffic infrastructure and travel demand management [1].

The parking charge has immerged as one of the most powerful policies of traffic demand management. Parking charge means that the drivers directly pay for the use of parking space (on-street or off-street) and it represents the most practical method of introducing or modifying the charge drivers are paying to use their passenger cars. It is usually introduced in the city centres.

Since the users are particularly sensitive to direct travel costs [2], because of the introduction of parking charge some users choose to abandon previous practice of coming into the city centre by passenger cars. Instead, for coming into the city centre they can use alternative transport mode, change time of day they are making the trip or even cancel such trip or change the destination. In this way the contribution to parking demand and supply balance in the area is ensured along with the mitigation of traffic congestion - parking charge is deemed the "second best measure" to solve the congestion problem, immediately after congestion charging [3]. Moreover, this policy generates 
income which can be used to further improve parking or transport system in general [4].

In order to achieve the set objectives of introducing the parking charge and minimizing possible undesirable impacts, when defining the parking price, its effects must be foreseen. Since such effects are under great influence of numerous local factors it is not possible to directly rewrite the experiences from other cities [5]. The impact of introducing or modifying parking charges can be estimated on the basis of the "before and after" studies. However, this data is frequently unavailable or it is difficult to isolate the impact of parking charge from other impacts. Hence, the stated preference approach is usually used.

The impact of the parking charge on the parking demand is frequently expressed through the elasticity coefficient denoting by how many percent the parking demand will change with $1 \%$ change of its price. Previous studies show that the elasticity of the parking demand on the parking price (obtained both empirically or by modelling) range between -0.1 and -0.6 with -0.3 as the most frequently cited value. The negative sign shows that the number of demands is decreasing with an increase in price, whereas absolute coefficient value less than 1 indicates inelastic demands [6]

Recently, it has been recognized that it is not sufficient only to provide balance between demand and supply, but that it is also necessary to take care of the structure of drivers who will park within the area and also of those who will be "repelled" by the parking price. This is necessary in order to satisfy the requirements of the, so called, qualified demand and in order for the city centre facilities not to lose their users and/or in order for the city centre not to lose its competiveness and economic efficiency. This means that the change in demand as response to the parking price should not be viewed at an aggregate level, but rather at a disaggregate level. However, although aggregate effect of the parking charge to traffic demand management is frequently noticed or assessed, a possible different impact on a specific demand sub-group is often neglected. This was pointed out also by Marsden [7] in his review article about the parking policies. Namely, among the topics dealing with parking requiring further research he identified in the first place: "the importance of out-of-vehicle costs and in particular walk-times on parking behaviour. Within this, greater attention should be paid to the segmentation of the parking market".

In this regard some studies have been initiated recently in order to get a better insight into the behaviour of the users faced with different parking policies, first of all, with the parking charge.

The purpose of this paper is to investigate the factors affecting the change in behaviour of the parking garage users when parking price is changed on the example of two parking garages in the central area of Belgrade, Serbia. In addition, the choice of alternatives and the factors affecting such choice will be studied.

The structure of the paper is as follows: Section 2 provides a short overview of literature significant for this paper. Then Section 3 describes parking conditions in Belgrade, especially within its central area. The description of survey methodology in Section 4 is followed by an analysis of the obtained results in Section 5 . Sections 6 and 7 present the results of the developed binary and multinomial logit model, respectively. Finally, Section 8 provides a summary of concluding considerations.

\section{LITERATURE OVERVIEW}

Shiftan and Burd-Eden [8] evaluated the probable user response to two alternative policies in the central business district in Haifa, Israel: increase in the parking price and decrease in the parking space availability expressed through increased parking search time. The results of the developed binary logit model show that the users with the purpose work are more inert to introduction of the above parking policies than other users. The multinomial logit model has shown that the drivers with the purpose work are more likely to change transport mode or time of day than cancel the trip or change the destination.

Tsamboulas [9] has developed a model for the conditions in the CBD in Athens, to estimate the probability of passenger car use when the parking price is increased, as well as the drivers' behaviour in choosing the parking location with several parking price combinations and walking distances. Unlike other papers, here the users are divided into two groups. The first group is made of the users who have concluded a contract with the owner of a certain car park allowing them to park their vehicles at that location irrespective of the time of day or parking duration and they pay for parking at a monthly level. The second group consists of the users who pay parking per hour. They do not have a reserved parking space, but search to find one and they have different criteria from the drivers who pay parking on a monthly basis. It has been shown that the behaviour of these two groups of users when faced with parking price increase is affected by different parameters.

Kelly and Clinch [10], on the basis of the data gathered at on-street car parks in the central business district of Dublin, Ireland, and ordered probit model, investigated the differences in response to parking price between the users with the purpose business and other users. It has been shown that while at lower price levels there are no significant differences in response between these two categories, the difference progressively increases as price increases. This indicates that 
there is a price threshold at which different groups of drivers start to behave differently.

Washbrook et al. [5] in Greater Vancouver investigated the mode choice of the commuters who at present drive alone as a response to the introduction of financial disincentives for single occupants and the improvement of alternative transport modes. The results obtained suggest that the increase in drive alone costs would lead to greater reductions of SOV demand than the increase in SOV travel time or decrease in travel time and costs of alternative transport modes.

Van der Waerden et al. [11] investigated the changes in driver behaviour regarding planned parking measures at the campus of the Eindhoven University of Technology in the Netherlands. The multinomial logit analysis included travel frequency and source, arrival time, relation with the university, driver's age and gender. It has been shown that almost a half of the drivers would change their behaviour if they had to pay the entry into the campus area by changing the transport mode or parking outside the campus area.

Khodaii et al. [12] investigated the behaviour of the drivers of the central business district in Teheran (hypothetically) with different parking prices. The objective of the article was to determine the variables influencing the user response at different parking price levels and the goal was to define the critical values of parking fares (the price at which the users would refrain from using their own cars). Based on the data gathered by an interview a logit model was made. It was concluded that the travel time and the monthly income of the users are the parameters mostly affecting car use and that $99 \%$ of the drivers would abandon the use of their passenger cars at an increase of price by $133 \%$ (from 3,000 IRR per hour (0.19 euro per hour) to 7,000 IRR per hour $(0.44$ euro per hour)).

\section{PARKING IN BELGRADE}

Belgrade is the capital of Serbia. The urban part of the city covers an area of about 77,000 ha and it has approximately 1.5 million inhabitants. About 96,000 inhabitants live in the CBD covering an approximate area of 440ha.

Based on the traffic survey, the inhabitants of Belgrade make approximately three million trips per day. In the modal split, the share of passenger cars is $22 \%$ and public transport $52 \%$ of all the daily person trips. In the peak hour, the share of passenger cars is $23 \%$ and public transport 58\%. The coverage with public transport network is about $2.1 \mathrm{~km} / \mathrm{km} 2$; headways are between 6 and 20 minutes and in the peak hour they are 2 to 10 minutes. The public transport users assess the quality of service as very good (mark near to 4 of maximum 5) [13].
The parking problem in Belgrade is present almost in its entire urban area. The parking problem arises as a result of obvious disproportion between the parking demand in the existing conditions and the number of available parking spaces. The basic characteristic of Belgrade is insufficient off-street public parking capacity so that the majority of vehicles are parked on the streets.

In the central area of Belgrade there are only 5 public parking garages. Their capacity presents $14 \%$ of the total static capacity for parking. The remaining capacity is at on-street (82\%) and off-street car parks (4\%). All parking spaces (including those in parking garages) are under the jurisdiction of the City Administration which is, therefore, in charge of the parking tariff system creation.

On working days from 7 a.m. to 9 p.m. and on Saturdays from 7 a.m. to 2 p.m. restrictive parking regime is applied to on-street parking. This regime implies time restriction and parking charge. The regime attributes depend on the parking zone: (i) in the red zone parking is limited to one hour and the parking price during the survey period was RSD 41 ( 1 euro $=100$ $\mathrm{RSD}^{1}$ ), (ii) in the yellow parking zone parking is limited to two hours and its price was RSD 29 per commenced hour of parking, and (iii) in the green parking zone visitors pay RSD 23 per commenced hour of parking for a maximum duration of three hours. In addition, the residents and legal entities having their headquarters within the zone, under certain conditions, have the right to acquire a parking permit which does not guarantee a vacant parking space but enables parking without any time limitation.

Parking is charged at all off-street car parks and in parking garages every day between 00 and 24 hours. The parking price is RSD 60 per commenced hour of parking. In addition, the users (physical and legal persons) have the right to buy monthly parking subscription tickets. The price of this ticket depends on its type and validity and on the parking garage itself. A monthly ticket that is valid from 00 to 24 hours amounts from RSD 12,000 to RSD 19,800 for individuals and from RSD 15,000 to RSD 28,250 for businesses. A reserved parking space in the garage costs monthly from RSD 10,000 to RSD 23,800 for individuals and from RSD 14,500 to RSD 34,950 for businesses. The monthly fee that is valid from 17 to 08 hours on weekdays and from 00 to 24 hours on weekends (and is primarily intended for residents) costs RSD 3,960.

During increased area attractiveness all on-street parking spaces are occupied and even illegal parking occurs, making it hard to find a vacant parking space. On the other hand, off-street car parks and parking garages are never $100 \%$ occupied and it can be said that at every moment a vacant parking space can be found.

Parking enforcement is carried out by three competent authorities: PUC "Parking servis", Communal Po- 
lice and Traffic Police. PUC "Parking servis" sanctions exceeding of time limit and unpaid fee for parking. In these cases the penalty amounts to RSD 1,870. The Communal Policy controls the use of reserved parking spaces and the use of parking lots according to traffic signalization. The penalty for this type of offense is RSD 5,000. Parking enforcement on the places where parking is prohibited is done by the Traffic Policy in cooperation with PUC "Parking servis". If illegally parked vehicle jeopardises the traffic efficiency and safety, the Traffic Policy may instruct the PUC "Parking servis" to remove the vehicle. The price of transporting the vehicle varies from RSD 1,750 to RSD 22,000 depending on the vehicle weight.

Parking enforcement is not the primary activity of the Traffic Police, and so the effectiveness of enforcement is limited.

\section{SURVEY METHODOLOGY}

\subsection{Survey area}

Unlike other studies relating to the users of onstreet and off-street car parks this paper investigates the behaviour of parking garage users. The authors chose the parking garages because time restricted regime does not apply to them, and thus long-term parkers can park there in the way that suits them.

Two public parking garages in Belgrade central area: Pionirski Park and Zeleni Venac represent the survey area of this paper. Pionirski Park is a 3-storey underground garage, with a total capacity of 472 parking spaces. On the average the parking volume rate is 1,650 vehicles every day. During the period of increased area attractiveness ( 8 a.m. to 8 p.m.), the garage is occupied $70 \%$ on the average, while its maximum occupancy is $92 \%$. Zeleni Venac has 11 aboveground semi-levels with a capacity of 306 parking spaces, and the average daily parking volume rate is 922. The maximum utilisation of the parking garage is $83 \%$, and the average utilisation in the period between 8 a.m. and 8 p.m. is $62 \%$.

\subsection{Gathering the necessary data}

For the needs of this paper the data have been gathered by direct interviewing of the parking garage users. The interviews were conducted by the students of the Faculty of Transport and Traffic Engineering, University of Belgrade.

The interview included three different data groups: (i) social and economic characteristics of passengers, (ii) trip characteristics, and (iii) user response to hypothetical changes in parking prices.

The passenger characteristics included gender, age and average monthly income per household mem- ber. However, since previous surveys have shown that frequently the respondents are not willing to answer questions about their income [8] or give incorrect answers, in addition to income itself two potential proxies for income were also determined: vehicle age and engine size.

Among trip characteristics the following was investigated: trip origin and destination, purpose, parking frequency and duration, method of payment of particular parking (per hour or a monthly subscription holder) and who bears the parking costs (the user or the employer). Since in the parking garage it is possible to find a vacant parking space at any moment, whereas it is very hard to find one on the street, as well as due to the differences in parking prices at these two places, the users were asked whether they had tried to find an on-street parking space before coming into the garage. They were also asked what the reason for such behaviour was: parking price or something else (proximity of destination, complicated driving and manoeuvring, etc.). The last trip characteristic relates to the fact whether the users attempt to reduce the parking duration and thus parking costs as well.

In the last part of the interview the users expressed their opinion whether and at what parking price they would discontinue to park in the garage: RSD 80, 100, 120 and 140 per hour (which represents an increase of $33.3 \%, 66.7 \%, 100.0 \%$ and $133.3 \%$, respectively). The users who answered that they would change their behaviour at a certain price were asked what they would do in such a case: park at on-street car parks, park at a location where there is no parking charge and continue by public transport, shift to public transport, carpool, discontinue coming into the central area and perform activity at some other destination, cancel the trip. If a respondent found that none of the answers offered could be chosen as their response, such a respondent was allowed to write the answer in their own words.

For gathering the data from the first two groups the revealed preference method was used while the stated preference method was used for the data relating to hypothetical situations (the third group).

The interview was conducted on Thursday, March 4, 2010 in the period from 8 a.m. to 8 p.m. (period of increased attractiveness of the central area).

\section{DATA ANALYSIS}

There were 261 users interviewed, which is $10.1 \%$ of the total parking volume. Their distributions according to the above mentioned, selected characteristics of passengers, trips and stated responses to price change are presented in Tables 1, 2 and 3, respectively. 
Table 1 - Distribution of users by passenger characteristics

\begin{tabular}{|c|c|c|c|}
\hline Characteristic & Category & Frequency & Percentage \\
\hline \multirow{3}{*}{ Gender } & Male & 185 & 70.9 \\
\hline & Female & 71 & 27.2 \\
\hline & Unknown & 5 & 1.9 \\
\hline \multirow{5}{*}{ Age } & $18-30$ & 76 & 29.1 \\
\hline & $30-45$ & 131 & 50.2 \\
\hline & $45-60$ & 49 & 18.8 \\
\hline & $>60$ & 3 & 1.1 \\
\hline & Unknown & 2 & 0.8 \\
\hline \multirow{3}{*}{ Monthly income (RSD) } & Up to 30,000 & 115 & 44.1 \\
\hline & Exceeding 30,000 & 117 & 44.8 \\
\hline & Unknown & 29 & 11.1 \\
\hline \multirow{4}{*}{ Vehicle age } & $<5$ years & 83 & 31.8 \\
\hline & $5-10$ years & 100 & 38.3 \\
\hline & $>10$ years & 77 & 29.5 \\
\hline & Unknown & 1 & 0.4 \\
\hline \multirow{5}{*}{ Engine size $\left(\mathrm{cm}^{3}\right)$} & Up to 1,000 & 8 & 3.1 \\
\hline & $1,000-1,500$ & 104 & 39.8 \\
\hline & $1,500-2,000$ & 124 & 47.5 \\
\hline & Exceeding 2,000 & 15 & 5.7 \\
\hline & Unknown & 10 & 3.8 \\
\hline
\end{tabular}

The majority of users are male (71\%) under 45 years of age (81\%). An almost equal number of users has a monthly income per household member of up to and over RSD 30,000. The average age of the vehicles is 15.6 years, and $87.3 \%$ vehicles have engine size of $1,000-2,000 \mathrm{~cm}^{3}$.

As regards trip characteristics, $82.0 \%$ of users drive to the garage less than $15 \mathrm{~km}$, or they may be said to come from the Belgrade area. There are 55.2\% users who walk up to $300 \mathrm{~m}$ to reach their final trip destination, and on the average they walk $370 \mathrm{~m}$.

There are $36.8 \%$ drivers coming with the trip purpose business, $22.2 \%$ with the purpose work, and $9.2 \%$ with the purpose shopping. The purposes private business, recreation etc. are classified into the category other, accounting for $31.8 \%$ of users. There are $15.3 \%$ users who park every day in the observed garage. Sixty-one percent of (61\%) of users have parking duration 2 hours, i.e. fit into the time restriction applicable to on-street car parks of the influential area for these garages. Twenty-three point eight percent $(23.8 \%)$ of users try to shorten the stay in the garage in order to reduce their parking costs.

Only 6 interviewed users owned the subscription tickets, whereas other users paid parking per hour. Since these two groups differ [9] and since only $2.3 \%$ users have subscription tickets, in the developed models such users were not taken into account. Thus, the sample was reduced to 255 . For $19.9 \%$ users park- ing costs are borne by their employers. Fourteen (14) users $(5.4 \%)$ tried to park at on-street parking space before coming into the garage because of the price difference.

As regards the obtained data about hypothetical situations, it can be concluded that $46.4 \%$ of users would never discontinue coming into the garage by passenger cars, no matter how much it was charged to park there. However, there still remains sufficient space to manage parking demand by the parking price. The users who would quit parking at a certain price would shift to public transport and on-street parking. Taking into account the occupancy of onstreet parking capacity it can be concluded that this other category is connected with the drivers' readiness to commit violation. A small percentage of users would change the destination or cancel the trip entirely (1.9\% and $0.4 \%$, respectively); thus, it can be said that the parking price increase would not significantly affect the attractiveness of the central area or the citizens' mobility.

\section{BINARY LOGIT MODEL}

The binary logit model was used to identify the parameters influencing the choice of parking garage users in the central area of Belgrade in case of parking price change: continue to park in garages or behaviour change. 
Table 2 - Distribution of users by trip characteristics

\begin{tabular}{|c|c|c|c|}
\hline Characteristic & Category & Frequency & Percentage \\
\hline \multirow{3}{*}{ Driving distance } & Up to $15 \mathrm{~km}$ & 214 & 82 \\
\hline & Exceeding 15 km & 44 & 16.9 \\
\hline & Unknown & 3 & 1.1 \\
\hline \multirow{3}{*}{ Walking distance } & Up to $300 \mathrm{~m}$ & 144 & 55.2 \\
\hline & Exceeding 300 m & 113 & 43.3 \\
\hline & Unknown & 4 & 1.5 \\
\hline \multirow{4}{*}{ Purpose } & Shopping & 24 & 9.2 \\
\hline & Business & 96 & 36.8 \\
\hline & Work & 58 & 22.2 \\
\hline & Other & 83 & 31.8 \\
\hline \multirow{4}{*}{ Frequency } & Every day & 40 & 15.3 \\
\hline & Few times a week & 66 & 25.3 \\
\hline & Few times a month & 98 & 37.5 \\
\hline & Less than that & 57 & 21.8 \\
\hline \multirow{4}{*}{ Parking duration (hours) } & Up to 1 & 74 & 28.4 \\
\hline & $1-2$ & 85 & 32.6 \\
\hline & $2-3$ & 23 & 8.8 \\
\hline & Exceeding 3 & 79 & 30.3 \\
\hline \multirow{3}{*}{ Duration shortening } & Yes & 62 & 23.8 \\
\hline & No & 196 & 75.1 \\
\hline & Unknown & 3 & 1.1 \\
\hline \multirow{2}{*}{ Method of payment } & Monthly subscription & 6 & 2.3 \\
\hline & Payment per hour & 255 & 93.9 \\
\hline \multirow{3}{*}{ Who bears parking costs } & Company & 52 & 19.9 \\
\hline & User & 208 & 79.7 \\
\hline & Unknown & 1 & 0.4 \\
\hline \multirow{4}{*}{$\begin{array}{l}\text { Parking space search at } \\
\text { on-street car parks }\end{array}$} & No search & 212 & 81.2 \\
\hline & Up to 5 minutes & 16 & 6.1 \\
\hline & From 5 to 10 minutes & 15 & 5.7 \\
\hline & Exceeding 10 minutes & 18 & 6.9 \\
\hline \multirow{4}{*}{$\begin{array}{l}\text { Reason for searching for } \\
\text { on-street parking }\end{array}$} & Parking price & 14 & 5.4 \\
\hline & Proximity of destination & 27 & 35.5 \\
\hline & Complicated driving and manoeuvring & 7 & 9.2 \\
\hline & Unknown & 1 & 1.3 \\
\hline
\end{tabular}

Since the users' responses were recorded for four offered parking prices all the answers were taken into account; thus, the sample of those interviewed was increased four times and now it is 1,020. In doing this it was understood that if a user stated that they would, for example, discontinue parking at the price of RSD 80 , such user would do the same at the prices of RSD 100, 120 and 140 .

The selection of the variables to be included into the model was made on the basis of the Wald test for significance of individual variables and log-likelihood differences for the significance of the entire model $[14,15]$.
The model includes nine variables, two of which relate to user characteristics, six to trip characteristics and the last one is the parking price per hour. To present the model (Table 4) the following characteristics were selected: variable name, parameter estimates, standard error, Wald statistics, significance and exp b [16]. Each variable included into the model will be discussed below.

"Young" is a dummy variable that equals 1 if the driver is under the age of 45 , and equals 0 otherwise. The coefficient has a positive value, indicating that it is more likely that younger users would give up parking than the older ones. Hess [17] and Takama \& Preston 
Table 3 - Distribution of users by stated response to parking price change

\begin{tabular}{||c|l|c|c||}
\hline \multicolumn{1}{|c|}{ Characteristic } & \multicolumn{1}{|c|}{ Category } & Frequency & Percentage \\
\hline \hline \multirow{4}{*}{$\begin{array}{l}\text { Price at which they would give } \\
\text { up parking in garage (RSD) }\end{array}$} & 80 & 55 & 21.1 \\
\cline { 2 - 4 } & 100 & 42 & 16.1 \\
\cline { 2 - 4 } & 120 & 31 & 11.9 \\
\cline { 2 - 4 } & 140 & 12 & 4.6 \\
\cline { 2 - 4 } & Never, irrespective of the price & 121 & 24.1 \\
\hline \multirow{5}{*}{ Alternative } & Public transport & 63 & 16.5 \\
\cline { 2 - 4 } & On-street parking within the zone & 43 & 6.5 \\
\cline { 2 - 4 } & $\begin{array}{l}\text { Parking at zone fringes and coming } \\
\text { into the zone by public transport } \\
\text { (informal Park and Ride) }\end{array}$ & 17 & 1.9 \\
\cline { 2 - 4 } & Taxi & 5 & 1.9 \\
\cline { 2 - 4 } & Destination change & 5 & 0.8 \\
\cline { 2 - 4 } & Carpool & 2 & 0.8 \\
\cline { 2 - 4 } & Motorcycle & 2 & 0.4 \\
\cline { 2 - 4 } & Cancel the trip & 1 & 0.4 \\
\cline { 2 - 4 } & Other & 1 & 0.4 \\
\cline { 2 - 4 } & Unknown & 5 & 2 \\
\hline \hline
\end{tabular}

[18] also concluded that younger population can be more easily influenced by parking measures.

Out of three parameters studied as the indicators of users' economic power it was determined that it is the age of passenger car that in the best way describes the sensitivity of users to the parking price. It is more difficult for the users whose cars are less than 5 years old to give up parking in the garage, those whose cars are between 5 and 10 years old do it somewhat more easily, whereas parkers whose cars are over 10 years old are markedly sensitive to the parking price.

"Short drive" is a dummy variable that equals 1 if the driver drove less than $15 \mathrm{~km}$ to reach the garage, and equals 0 otherwise. Positive coefficient indicates that the users driving shorter distances are more sensitive to price because parking costs have higher share in the total travelling costs. This has been also confirmed by Van der Waerden et al. [11], while the opposite conclusion was reached by Tsamboulas [9].

Unlike other papers in which the purposes were observed as: business and non-business [10], work and non-work [12], work own business and other [9], in this paper a detailed segmentation of purposes was made. Namely, the purposes were divided into: shopping; business; work and other, which includes private business, recreation, etc. and sensitivity was assessed in relation to these purposes. The results show that it is most likely that the users with the purpose work would discontinue to park in the garage because of the price. Since parking is paid per hour and the users with the purpose work have the longest parking duration, such response is expected. Less sensitive are the users with the purpose shopping, and particularly those with the purpose business. Such user response is favourable for the policy makers. The users, namely, with the purpose work are blocking parking spaces for a longer period of time and travel during peak hours, thus they are deemed undesirable in the city centres. On the other hand, users with the purpose business are favoured in such areas. Nevertheless, attention should be paid to the users with the purpose shopping who are sensitive to the parking price and are of vital importance for the attractiveness and competiveness of the central area.

"Everyday user" is a dummy variable that equals 1 if a user parks in the observed garage at least 5 times a week, and equals 0 if they park in the garage more rarely. Everyday users are more sensitive to price than those who park more rarely because these users are burdened more by the increase in parking fees.

"Shorten duration" is a dummy variable that equals 1 if users try to shorten the parking duration in order to reduce the parking costs. Their chances are four times higher to discontinue parking in the garage than of the parkers who do not pay attention to this.

As expected, the users whose parking is paid by their employers do not pay much attention to the parking price, unlike those who pay the parking costs by themselves.

It is expected that the users who tried to park at onstreet parking space prior to coming into the garage in order to reduce their parking costs are more sensitive to the parking price. This model has confirmed this.

The number of users who would give up parking in the garage increases as the parking prices rise.

The log-likelihood change test shows that the model is significant at $0 \%$ level and null hypothesis is rejected. Significance of each coefficient is less than 
Table 4 - Results of binary model

\begin{tabular}{|c|c|c|c|c|c|c|c|c|}
\hline \multirow{2}{*}{ Variable } & \multirow{2}{*}{$\begin{array}{l}\text { Estimated } \\
\text { Coef- } \\
\text { ficient }\end{array}$} & \multirow{2}{*}{$\begin{array}{c}\text { Standard } \\
\text { Error }\end{array}$} & \multirow{2}{*}{ Wald } & \multirow{2}{*}{ df } & \multirow{2}{*}{ Sig. } & \multirow{2}{*}{$\operatorname{Exp}(B)$} & \multicolumn{2}{|c|}{ 95\% C.I.for $\operatorname{EXP}(B)$} \\
\hline & & & & & & & Lower & Upper \\
\hline Young & 0.608 & 0.190 & 10.212 & 1 & 0.001 & 1.837 & 1.265 & 2.668 \\
\hline Passenger car age & & & 15.729 & 2 & 0.000 & & & \\
\hline - less than 5 years & -0.651 & 0.191 & 11.589 & 1 & 0.001 & 0.522 & 0.359 & 0.759 \\
\hline - from 5 to 10 years & -0.622 & 0.178 & 12.252 & 1 & 0.000 & 0.537 & 0.379 & 0.761 \\
\hline Short drive & 0.375 & 0.202 & 3.466 & 1 & 0.063 & 1.456 & 0.980 & 2.161 \\
\hline Purpose & & & 14.585 & 3 & 0.002 & & & \\
\hline - shopping & 0.648 & 0.258 & 6.320 & 1 & 0.012 & 1.912 & 1.153 & 3.168 \\
\hline - business & 0.458 & 0.191 & 5.745 & 1 & 0.017 & 1.581 & 1.087 & 2.298 \\
\hline - work & 0.727 & 0.211 & 11.872 & 1 & 0.001 & 2.069 & 1.368 & 3.129 \\
\hline Everyday users & 0.393 & 0.222 & 3.120 & 1 & 0.077 & 1.481 & 0.958 & 2.290 \\
\hline Shorten duration & 1.341 & 0.173 & 60.020 & 1 & 0.000 & 3.823 & 2.723 & 5.367 \\
\hline $\begin{array}{l}\text { Employer-paid } \\
\text { parking }\end{array}$ & -0.412 & 0.198 & 4.337 & 1 & 0.037 & 0.662 & 0.449 & 0.976 \\
\hline $\begin{array}{l}\text { Search for PS at } \\
\text { on-street car parks } \\
\text { because of price }\end{array}$ & 0.584 & 0.308 & 3.593 & 1 & 0.058 & 1.794 & 0.980 & 3.282 \\
\hline Parking price & 0.041 & 0.003 & 195.540 & 1 & 0.000 & 1.042 & 1.036 & 1.048 \\
\hline Constant & -6.147 & 0.454 & 183.381 & 1 & 0.000 & 0.002 & & \\
\hline
\end{tabular}

$-2 L(0)=1558.802$

$-2 L(M)=1198.787$

Percent of correct predictions (with probability choice > 50\%): $75.4 \%$

$-2[L(0)-L(M)]=360.015, d f=12, p<0.000$

0.05 , except for three coefficients for which it is less than 0.10 . Therefore, the null hypothesis that some parameter equals zero can be rejected at $5 \%$ (or $10 \%$ ) significance level. This model classifies accurately $75 \%$ of cases.

\section{MULTINOMIAL LOGIT MODEL}

Initially the multinomial logit model was considered with all the possible offered alternatives in the questionnaire (or added by the respondents). Because of limited choice of alternatives: carpool, change destination, cancel the trip, taxi, motorcycle and other, there was no possibility to make an adequate model with all individual answers or to merge the answers into a unique category "other". Therefore, a model without these options was made and the sample size for this model was 242.

The developed multinomial logit model (Table 5) estimates the probability of opting for one of the following alternatives by the user as a response to parking price change: (i) on-street parking within the zone, (ii) use of informal Park and Ride system, (iii) use of public transport, or (iv) without change in behaviour. The last category (without change in behaviour) was taken as the reference category.

The choice of variables included into the model was made on the basis of the analysis of significance of individual variables and the log-likelihood differences for the significance of the entire model. Eight independent variables were included, as follows: socioeconomic characteristics of users - driver age, vehicle age and engine size, and among trip characteristics - driving distance, parking frequency and duration, whether they take care of parking duration and parking search time.

The model accurately predicts $63 \%$ cases, and by chi-square test it was determined that it is significant at $5 \%$ level of significance. In addition, informal goodness-of-fit test $\rho^{2}$ was 0.25 (greater than minimum value 0.20 ), also indicating that the model is well fit to population [19]. Using residual analysis it was determined that more than $96 \%$ value of Pearson residuals was in the range \pm 2 .

A negative sign of constant coefficients shows that the majority of users will not change their behaviour because of an increase in the parking price in the garage. The most acceptable alternative for the users who would change their behaviour is public transport. All constant coefficients are significant at $5 \%$ level.

As shown by the binary model, the users under the age of 45 are more likely to change their behaviour as a response to increase in the parking price than those over the age of 45 . They prefer to opt for on-street parking, and then for informal Park and Ride. 
Table 5 - Results of MNL model

\begin{tabular}{|c|c|c|c|c|c|c|c|c|c|}
\hline & \multicolumn{3}{|c|}{ On-street parking } & \multicolumn{3}{|c|}{ Informal Park and Ride } & \multicolumn{3}{|c|}{ Shifting to public transport } \\
\hline Variable & $\begin{array}{l}\text { Estimated } \\
\text { coefficient }\end{array}$ & Sig. & $\operatorname{Exp}(B)$ & $\begin{array}{l}\text { Estimated } \\
\text { coefficient }\end{array}$ & Sig. & $\operatorname{Exp}(B)$ & $\begin{array}{l}\text { Estimated } \\
\text { coefficient }\end{array}$ & Sig. & $\operatorname{Exp}(B)$ \\
\hline Constant & -5.998 & 0.000 & & -6.067 & 0.004 & & -4.142 & 0.008 & \\
\hline Young & 2.851 & 0.007 & 17.303 & 2.162 & 0.059 & 8.691 & 0.188 & 0.684 & 1.206 \\
\hline \multicolumn{10}{|l|}{ Vehicle age } \\
\hline - less than 5 years & -0.591 & 0.290 & 0.554 & -0.889 & 0.276 & 0.411 & -0.992 & 0.032 & 0.371 \\
\hline - from 5 to $10 \mathrm{yr}$ & 0.075 & 0.881 & 1.078 & -0.609 & 0.401 & 0.544 & -1.006 & 0.030 & 0.366 \\
\hline \multicolumn{10}{|l|}{ Engine size } \\
\hline - up to $1,500 \mathrm{~cm}^{3}$ & 0.884 & 0.065 & 5.102 & 1.415 & 0.250 & 4.117 & 3.068 & 0.006 & 21.503 \\
\hline $\begin{array}{l}\text { - from } 1,501 \text { to } \\
2,000 \mathrm{~cm}^{3}\end{array}$ & 0.871 & 0.155 & 3.453 & 0.721 & 0.558 & 2.056 & 2.028 & 0.071 & 7.599 \\
\hline Short drive & 0.268 & 0.638 & 1.307 & -0.242 & 0.742 & 0.785 & 0.662 & 0.197 & 1.939 \\
\hline \multicolumn{10}{|l|}{ Frequency } \\
\hline - every day & 1.105 & 0.180 & 3.018 & 1.788 & 0.122 & 5.975 & -0.734 & 0.280 & 0.480 \\
\hline - few times a week & -0.341 & 0.566 & 0.711 & 0.678 & 0.483 & 1.969 & -0.468 & 0.364 & 0.627 \\
\hline - few times a month & -0.549 & 0.295 & 0.578 & 0.451 & 0.627 & 1.570 & -1.121 & 0.020 & 0.326 \\
\hline \multicolumn{10}{|l|}{ Parking duration } \\
\hline - up to 1 hour & 1.812 & 0.013 & 6.124 & 0.547 & 0.590 & 1.727 & -0.305 & 0.554 & 0.737 \\
\hline - from 1 to 2 hours & 1.583 & 0.024 & 4.871 & 0.768 & 0.345 & 2.156 & -1.071 & 0.041 & 0.343 \\
\hline - from 2 to 3 hours & 2.144 & 0.017 & 8.536 & 2.126 & 0.030 & 8.385 & -1.062 & 0.176 & 0.346 \\
\hline Shorten duration & 2.014 & 0.000 & 7.494 & 3.098 & 0.000 & 22.163 & 2.211 & 0.000 & 9.122 \\
\hline \multicolumn{10}{|c|}{ Search for parking space at on-street car parks } \\
\hline - do not search & -0.780 & 0.279 & 0.458 & -0.362 & 0.714 & 0.696 & 1.824 & 0.060 & 6.196 \\
\hline - up to $5 \mathrm{~min}$ & 0.310 & 0.742 & 1.363 & -0.465 & 0.757 & 0.628 & 1.766 & 0.155 & 5.846 \\
\hline - from 5 to $10 \mathrm{~min}$ & 0.549 & 0.605 & 1.731 & 1.140 & 0.412 & 3.126 & 2.812 & 0.024 & 16.646 \\
\hline
\end{tabular}

$-2 L(0)=504.190$

$-2 L(M)=377.949$

Percent of correct predictions (with probability choice > 50\%): $63.0 \%$

$-2[L(0)-L(M)]=126.241>X^{2} 0.05,50=67.505$

The drivers owning cars older than 10 years are more likely to accept use of informal Park and Ride or public transport as compared with the drivers owning vehicles less than 10 years old.

The owners of the cars having engine size less than $1,500 \mathrm{~cm}^{3}$ are more likely to accept some of the offered alternatives as compared to other two user categories (from 1,501 to $2,000 \mathrm{~cm}^{3}$ and exceeding $2,000 \mathrm{~cm}^{3}$ ). For this user category the most acceptable option is shifting to public transport, and then on-street parking. This can be explained by the fact that the users driving vehicles with engine size up to $1,500 \mathrm{~cm}^{3}$ have less fuel consumption, thus the share of parking costs in the total travel costs is greater due to the increase in the parking price.

The users travelling the distance less than $15 \mathrm{~km}$ are more likely to park on the street or shift to public transport. The users travelling the distance in excess of $15 \mathrm{~km}$ who are willing to change their behaviour opt for informal Park and Ride in the first place.
Everyday garage users, because of increase in the parking price, will rather accept informal Park and Ride or on-street parking as compared to other categories. On the other hand, they have negative coefficient for public transport, indicating that they are less ready to use public transport as an alternative than those parkers who park in the garage less frequently. It can be concluded that these drivers find it most difficult to renounce comfort of a passenger car.

Short-term parkers (parking duration less than 3 hours) as compared to long-term parkers (exceeding 3 hours) are more likely to park on the street or to use informal Park and Ride than to change their behaviour. On the other hand, long-term parkers have greater chance to shift to public transport than short-term parkers. This can be explained by the fact that on-street parking alternative is not acceptable for long-term parkers because of the time restricted regime. Also, the option to use informal Park and Ride system is less acceptable to these users than to parkers with parking duration less than 3 hours. Informal Park and Ride is 
mostly acceptable to the users with parking duration between 2 and 3 hours. Examining the structure of the users with this parking duration it was established that in $80 \%$ of cases these are the users with the purpose business, recreation and private business.

The users attempting to shorten the parking duration, and thus parking costs, are more likely to change their behaviour than to continue to park in the garage. All three coefficients are positive with the significance level 0.00. The mostly acceptable alternative for these users is informal Park and Ride.

The users who searched for on-street parking space longer than 10 minutes before coming into the garage are the least ready to accept public transport as an alternative. This shows their persistence to come into the city centre by car, although this implies additional costs in time and money. The users who did not search for on-street parking space obviously travel into the city centre with the intention to park in the garage, thus they are less ready to park on the street or to use informal Park and Ride.

\section{CONCLUSION}

The influence of the parking charge on the behaviour of parking garage users in the central area of Belgrade was investigated in this paper. The binary and multinomial logit models were developed for this analysis by using the data obtained from the revealed and stated preferences.

The binary model shows that the number of users who would give up parking increases as the parking price increases. This confirms the opinion that parking (travel) demand can be managed by the parking price. It should be pointed out that the user sensitivity might be different if enforcement at on-street car parks were stricter, so that illegal on-street parking is not viewed as an alternative by parkers.

When the parking demand is viewed at disaggregate level it can be noticed that the users with the purpose work are the most sensitive to the parking price. Such a response is favourable because the drivers who are "undesirable" in the city centres, because of time of day they are travelling and their parking duration, are the users who would most readily give up parking. Although the users with the purpose shopping and business, who are important for the vitality and competiveness of the area, are also sensitive to the parking price, it seems that there is no much reason to worry because only $4.1 \%$ of users with the purpose shopping and $2.1 \%$ of the users with the purpose business would discontinue to come into the central area because of the increase in the parking price.

The parameter "shorten duration" has been introduced for the first time in the binary model. This parameter is connected with the drivers' effort to short- en duration, and thus total parking costs. In this way the sensitivity of users to the parking price is directly depicted. Among all the parameters included into the model this parameter has the greatest statistical significance and mostly affects the choice of users (sig. $=0.000, \operatorname{Exp}(B)=3.823$, Table 4).

The users who would change their behaviour because of the price increase would shift to public transport in most cases. Because of this, such a measure should be accompanied by the research of the needs for public transport system improvement, first of all in terms of the increase in capacity.

Furthermore, the results of the multinomial logit model warn that an increase in the parking price might lead to great parking demand at on-street parking facilities (already having high occupancy level), which would increase the time of parking space search.

By comparing the influence of some parameters on the response to price increase with the influence provided in literature it can be concluded that such models should not be rewritten from experience of other cities, but that they should be developed for each case separately.

\section{JELENA SIMIĆEVIĆ}

E-mail: j.simicevic@sf.bg.ac.rs

Dr NADA MILOSAVLJEVIĆ

E-mail: n.milosavljevic@sf.bg.ac.rs

Univerzitet u Beogradu, Saobraćajni fakultet

Vojvode Stepe 305, 11000 Beograd, Srbija

GORAN MALETIĆ

E-mail: goran.maletic@institutims.rs

Institut IMS

Bulevar vojvode Mišića 43, Beograd, Srbija

\section{SAŽETAK}

\section{UTICAJ CENE PARKIRANJA NA PONAŠANJE KORISNIKA PARKING GARAŽA}

Naplata parkiranja se smatra moćnim alatom za rešavanje problema parkiranja i saobraćajnih zagušenja. Kako bi se realizovali očekivani efekti bez negativnih uticaja, potrebno je dobro razumeti reakcije koje ova politika izaziva kod korisnika. U ovom radu, na osnovu uzorka anketiranih korisnika parking garaža, razvijen je binarni logit model za identifikaciju i kvantifikaciju karakteristika korisnika i putovanja od kojih zavisi prihvatanje cene parkiranja. Uz to, multinominalni logit model je napravljen kako bi se predvideo izbor korisnika kada se suoče sa povećanjem cene parkiranja. Rezultati pokazuju da su korisnici sa motivom "rad" najosetljiviji na povećanje cene parkiranja, što se može smatrati pozitivnim za donosioce politike. Međutim, velika osetljivost korisnika sa motivom "kupovina” treba da izazove njihovu zabrinutost. Rezultati multinominalnog modela pokazuju da oni ipak ne bi odustali od dolaska u zonu.

\section{KLUČNNE REČI}

politika parkiranja, naplata parkiranja, ponašanje korisnika, logit model, parking garaže 


\section{REFERENCES}

1. RSD rate and all prices specified in the paper relate to the time when the survey was conducted

\section{LITERATURE}

[1] Zhang, X., Van Wee, B.: Efficiency comparison of various parking charge schemes considering daily travel cost in a linear city, EJTIR, Vol. 11, no. 2, 2011, pp. 234-255

[2] Vuchic, V.: Transportation for livable cities, Centre for Urban Policy Research, New Jersey, United States of America, 1999

[3] Calthrop, E., Proost, S., Van Dender, K.: Parking policies and road pricing, Urban Studies, Vol. 37, 2000, pp. 63-76

[4] Litman, T.: Parking management: Strategies, evaluation and planning, Victoria Transport Policy Institute, 2010

[5] Washbrook, K., Haider, W., Jaccard, M.: Estimating commuter mode choice: a discrete choice analysis of the impact of road pricing and parking charges, Transportation, Vol. 33, 2006, pp. 621-639

[6] Transit Cooperative Research Program (TCRP): Traveller response to transportation system changes, Transportation Research Board, Washington DC, 2005

[7] Marsden, G.: The evidence base for parking policies a review, Transport Policy, Vol. 13, 2006, pp. 447-457

[8] Shiftan, Y., Burd-Eden, R.: Modelling the response to parking policy, Transportation Research Record, Vol. 1765, 2001, pp. 27-34, Transportation Research Board, Washington, DC
[9] Tsamboulas, D.: Parking fare thresholds: a policy tool, Transport Policy, Vol. 8, 2001, pp. 115-124

[10] Kelly, J. A., Clinch, J. P.: Influence of varied parking tariffs on parking occupancy levels by trip purpose, Transport Policy, Vol. 16, 2006, pp. 487-495

[11] Van der Waerden, P., Borgers, A., Timmermans, H.: Attitudes and behavioural responses to parking measures, EJTIR, Vol. 6, No. 4, 2006, pp. 301-312

[12] Khodaii, A., Aflaki, E., Moradkhani, A.: Modelling the Effect of parking fare on personal car use, Transaction A: Civil Engineering, Vol. 17, No. 3, 2010, pp. 209-216

[13] Jović, J., Djorić, V.: Application of transport demand modelling in pollution estimation of a street network, Thermal Science, Vol. 13, No. 3, 2009, pp. 229-243

[14] Agresti, A.: An introdustion to categorical data analysis, Second edition, John Wiley \& Sons, Inc., Hoboken, New Jersey, 2007

[15] Chatterjee, S., Hadi, A.S.: Regression analysis by example, Fourth edition, John Wiley \& Sons, Inc., Hoboken, New Jersey, 2006

[16] Field, A.: Discovering statistic using SPSS, Second edition, Sage Publication, London, 2005

[17] Hess, D.B.: Effect of free parking on commuter mode choice: Evidence from travel diary data, Transportation Research Record, Vol. 1753, 2001, pp. 35-42

[18] Takama, T., Preston, J.: Forecasting the effects of road user charge by stochastic agent-based modelling, Transportation Research Part A, Vol. 42, 2008, pp. 738-749

[19] Teknomo, K., Hokao, K.: Parking behaviour in central business district - a case study of Surabaya, Indonesia, EASTS Journal, Vol. 2, No. 2, 1997, pp. 551-570 